\title{
Pemanfaatan Senyawa Metabolit Sekunder Ekstrak Eter Diadema setosum dari Pantai Kukup dan Pantai Sundak Gunungkidul sebagai Antiinflamasi
}

\author{
Utilization of Secondary Metabolites Compounds from \\ Diadema setosum Ether Extract Originated from Kukup and Sundak Beaches \\ as Anti-Inflammatory
}

\author{
Yollanda Tiffany Susabda ${ }^{1}$, Aniek Prasetyaningsih ${ }^{1 *}$, dan Dwi Adityarini ${ }^{1}$ \\ ${ }^{1}$ Fakultas Bioteknologi, Universitas Kristen Duta Wacana Yogyakarta, Indonesia
}

\begin{abstract}
Abstrak
Bulu babi atau landak laut merupakan hewan laut yang tergolong dalam kelas Echinoidea. Kelompok hewan dari kelas Echinoidea mempunyai kemampuan menghasilkan metabolit sekunder yang memiliki efek farmakologis seperti antibakteri, antitumor dan kanker, antioksidan, dan antiinflamasi. Salah satu metabolit sekunder dari yang dihasilkan oleh hewan dari kelompok Echinoidea adalah Ovothiol-A yang berpotensi sebagai antiinflamasi. Penelitian ini bertujuan untuk mempelajari metabolit sekunder dari Diadema setosum yang berasal dari Pantai Selatan Gunungkidul dan studi potensinya sebagai antiinflamasi. Hasil uji KLT dan FTIR menunjukkan bahwa spesies Diadema setosum sebagai salah satu anggota Echinoidea diduga mengandung senyawa Ovothiol-A pada bagian organ maupun cangkangnya. Senyawa diduga sebagai Ovothiol-A yang dihasilkan oleh $D$. setosum memiliki kemampuan antiinflamasi yang ditunjukkan oleh penyempitan luka pada mencit yang diberi perlakuan ekstrak bagian organ (100\%) D.setosum dengan rata-rata penyempitan luka $0,44 \pm 0,256 \mathrm{~mm} /$ hari. Hasil dari penelitian ini menunjukkan bahwa ekstrak $D$. setosum memiliki senyawa Ovothiol-A yang dapat berfungsi sebagai antiinflamasi. Ekstrak $D$. setosum bagian organ memiliki kemampuan antiinflamasi yang lebih baik.
\end{abstract}

Kata kunci: metabolit sekunder, Diadema setosum, antiInflamasi, Pantai Sundak, Pantai Glagah, penyempitan luka

\section{Abstract}

Sea urchin is a sea organism that belongs to class Echinoidea. Species of echinoids is known to have abilitity to produce secondaries metabolites that have antibacterial, antitumor, anticancer, antioxidant, and antiinflammation effects at health like a. One of secondaries metabolites produced by echinoids is Ovothiol-A which has antiinflammation effect. This research aimed to study secondary metabolite content of Diadema setosum originated from Southern Beaches of Yogyakarta and their utilization as anti-inflamatory agent. This research showed that echinoid D. setosum contained Ovothiol-A compound as detected by TLC test and FTIR analysis. Ovothiol-A in D. setosum had an antiinflammation effect as shown by the decreasing of mice open wound diameter treated with D.setosum shell extract at concentration $50 \%$ and $100 \%$. Diadema setosum organ extract at concentration 100\% was measured to have the best potency in narrowing open wound of treated animal $(0,44 \pm 0,256 \mathrm{~mm} /$ day $)$. It can be concluded that $D$. setosum extracts contained Ovothiol-A that can be utillized as antiinflammation. Organ extract of D. setosum had better antiinflammation effect compared to its shell extract.

Keywords: secondary metabolites, Diadema setosum, antiinflamation, Sundak and Kukup Beaches, wound recovery

\footnotetext{
*Corresponding author:

Aniek Prasetyaningsih

Fakultas Bioteknologi, Universitas Kristen Duta Wacana

Jl. Wahidin Soedirohoesodo 5-25 Yogyakarta 55244, Indonesia

Email : aniek@staff.ukdw.ac.id
} 


\section{Pendahuluan}

Bulu babi atau landak laut merupakan salah satu biota laut yang tergolong dalam kelas Echinoidea, filum Echinodermata. Hewan echinoid banyak terdapat di perairan tenang dan jernih, dengan tingkat keragaman tertinggi ditemukan di daerah terumbu karang dan pantai yang dangkal (Rompis, 2013). Menurut Aziz (1993), terdapat 84 jenis Echinoidea di Perairan Indonesia yang menunjukkan keberagaman Echonidea di Indonesia cukup tinggi. Salah satu jenis Echinoidea yang banyak terdapat di Indonesia adalah Diadema setosum. Menurut Darsono \& Aziz (1979), D. setosum hidup menyebar di pantai yang memiliki terumbu karang dan juga berbatu. Selain keragamannya yang tinggi, Daerah Istimewa Yogyakarta memiliki banyak daerah pantai berkarang yang terletak di selatan Yogyakarta tepatnya di daerah Gunungkidul.

Kehidupan Echinoidea tidak terlepas dari predator. Hal ini menyebabkan Echinoidea akan mengembangkan sistem perlindungan diri seperti bentuk fisiologis berduri dan menghasilkan metabolit sekunder. Menurut Aprilia et al. (2012), Echinoidea menghasilkan metabolit sekunder seperti alkaloid, terpenoid, $\beta$-karoten, dan Ovothiol A yang berpotensi sebagai senyawa antibakteri dan antijamur yang dapat menghambat peradangan pada luka atau sebagai antiinflamasi.

Senyawa antiinflamasi merupakan suatu senyawa yang berfungsi untuk mencegah terjadinya peradangan pada luka.Salah satu penyebab luka meradang adalah munculnya bakteri dan jamur dalam jumlah berlebih seperti bakteri Staphylococcus aureus dan Candida albicans. Senyawa antiinflamasi ini sangat penting dalam bidang farmasi karena banyak obat yang membutuhkan sisipan senyawa anti inflamasi di dalamnya. Kandungan metabolit sekunder Echinoidea yang berpotensi sebagai senyawa antiinflamasi dapat digunakan untuk menggantikan keberadaan senyawa antiinflamasi sintetis atau kimiawi pada obat. Menurut Widiyantoro et al. (2012), antiinflamasi yang umum digunakan merupakan golongan steroid dan non steroid. Kedua golongan obat tersebut memiliki beragam efek samping untuk manusia mulai dari luka lambung akibat kenaikan asam lambung berlebih, penurunan imunitas hingga osteoporosis. Oleh karena itu, diperlukan pengembangan senyawa antiinflamasi dari bahan alam seperti tumbuhan dan hewan dengan efek samping rendah. Salah satunya dengan mengeksplorasi senyawa aktif pada Echinoidea yang belum dieksplorasi manfaatnya.

Berdasarkan uraian tersebut, penelitian ini bertujuan untuk mempelajari metabolit sekunder dari Diadema setosum yang berasal dari Pantai Selatan Gunungkidul dan studi potensinya sebagai antiinflamasi.

\section{Materi dan Metode \\ Lokasi Penelitian}

Pengambilan sampel D. setosum dilakukan di Pantai Sundak dan Kukup, Kabupaten Gunung Kidul, Daerah Istimewa Yogyakarta pada bulan Februari 2020.

Preparasi dan pengujian sampel dilakukan di Laboratorium Universitas Kristen Duta Wacana.

\section{Preparasi Sampel}

Diadema setosum yang dikoleksi dari Pantai Sundak dan Pantai Kukup dibawa ke laboratorium menggunakan ice box sebelum diproses lebih lanjut di laboratorium. Sampel kemudian ditimbang dan dipisahkan bagian cangkang dan organnya. Organ dan cangkang D. setosum didestruksi dengan mortar hingga tidak terdapat bagian yang menggumpal dan berbentuk serpihan-serpihan kecil. Sampel disimpan di dalam freezer pada suhu $-20^{\circ} \mathrm{C}$.

\section{Ekstraksi}

Proses ekstraksi terbagi menjadi dua tahap. Tahap yang pertama bertujuan untuk mendestruksi sampel D.setosum.Tahap pertama dilakukan dengan cara menimbang sampel bagian organ dan bagian cangkang D. setosum sebanyak 10 gram kemudian ditambahkan dengan $13 \mathrm{~mL} \mathrm{HCl} 1 \mathrm{M}$ dan 52 mL etanol 96\%. Campuran tersebut kemudian diletakkan di dalam shaker selama 1 x24 jam. Setelah itu, sampel disentrifuse dengan 
kecepatan $14.000 \mathrm{rcm}$ dalam suhu $4^{\circ} \mathrm{C}$ selama 15 menit. Supernatan yang didapatkan kemudian diuapkan menggunakan oven hingga volume berkurang.

Tahap kedua bertujuan untuk mendapatkan senyawa Ovothiol-A dari sampel. Tahap kedua dimulai dengan supernatant hasil ekstraksi dimasukkan ke dalam corong pisah dan ditambahkan dengan eter 1:1 (v/v). Sampel didiamkan selama $1 \times 24$ jam. Fase akuades diambil dan diuapkan menggunakan oven suhu $45^{\circ} \mathrm{C}$ hingga volume berkurang kurang lebih hingga tersisa $1 / 3$ volume awal.

\section{Pengendapan}

Pengendapan dilakukan untuk mendapatkan Ovothiol-A dari ekstrak sampel. Pengendapan dilakukan dengan mencampurkan sampel yang akan diendapkan dan larutan buffer phosphate $\mathrm{pH}$ 5,8 dengan perbandingan 1:1. Campuran tersebut kemudian divortex dan ditunggu hingga mengendap kurang lebih 15 menit), bagian atas dibuang perlahan dan diambil bagian endapan.

\section{Pengujian KLT}

Untuk pengujian KLT dilakukan dengan menggunakan eluen campuran n-butanol, asam asetat, dan air dengan perbandingan 3:1:1. Hasil yang didapatkan berupa nilai Rf. Nilai Rf tersebut dibandingkan dengan nilai Rf pada Devices (2017).

\section{Pengujian dengan FTIR}

Pengujian FTIR dilakukan dengan alat FTIR merk Nicolet Avatar 360 IR. Sampel yang digunakan untuk analisis menggunakan FTIR adalah ekstrak $D$. setosum yang telah diendapkan menggunakan Buffer phosphate dan berbentuk cair.

\section{Pengujian Antibakteri dan Antiajmur}

Pengujian antibakteri dan antijamur dilakukan dengan metode diffusion disk yaitu dengan meletakkan disk yang telah dicelupakn ke dalam ekstrak pada media NA dan PDA yang terdapat kultur bakteri Staphylococcus aureus dan jamur Candida albicans. Kemudian diamati pembentukan zona hambatnya.

\section{Pengujian Praklinis}

Pengujian praklinis dilakukan dengan membuat luka terbuka pada mencit jenis mus. Musculus. Luka terbuka dibuat dengan menggunakan alat biopsy punch sebesar $5 \mathrm{~mm}$. Luka tersebut kemudian diberi perlakuan dengan dioles ekstrak serta kontrol positif dan kontrol negatif. Kemudian diukur penyempitan diameter luka yang terjadi pada mencit tersebut selama 7 hari terhitung dari hari ke 0.

\section{Hasil}

\section{Kromatografi lapis tipis (KLT)}

Hasil Pengujian Kromatografi Lapis Tipis disajikan pada Gambar 1. Pengujian kromatografi lapis tipis dilakukan dengan menggunakan plat silika dan solvent n-butanol, asam asetat, dan air perbandingan 3:1:1

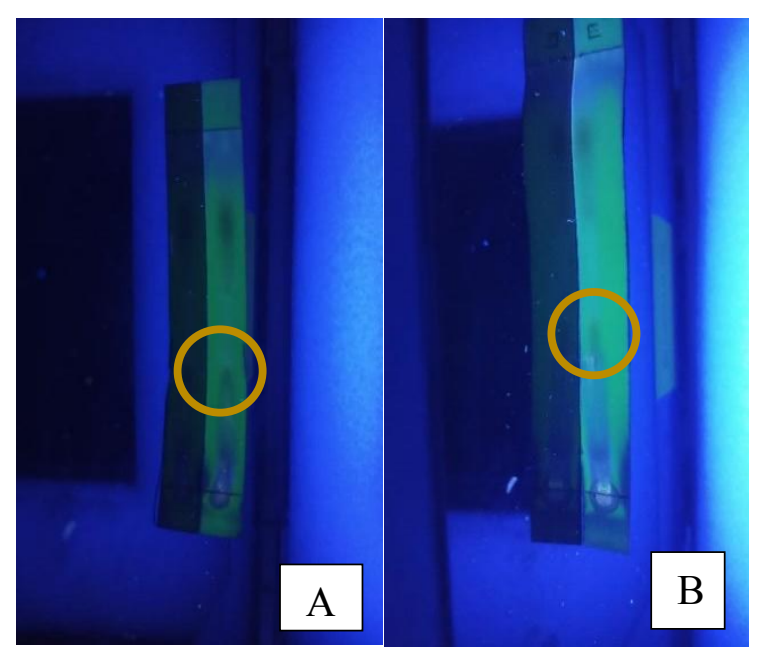

Gambar 1. Hasil Pengujian Kromatografi Lapis Tipis pada ekstrak (A) Bagian Cangkang dan (B) Bagian Organ Diadema setosum.

\section{Analisis Struktur Ovothiol-A dengan FTIR}

Hasil analisis stuktur Ovothiol-A menggunakan FTIR (Fourier Transform Infrared Spectroscopy) disajikan pada Gambar 2 dan Gambar 3. Gambar 2 adalah hasil analisis dari sampel ekstrak $D$. setosum bagian cangkang dan Gambar 3 adalah hasil analisis dari sampel ekstrak D. setosum bagian organ. 


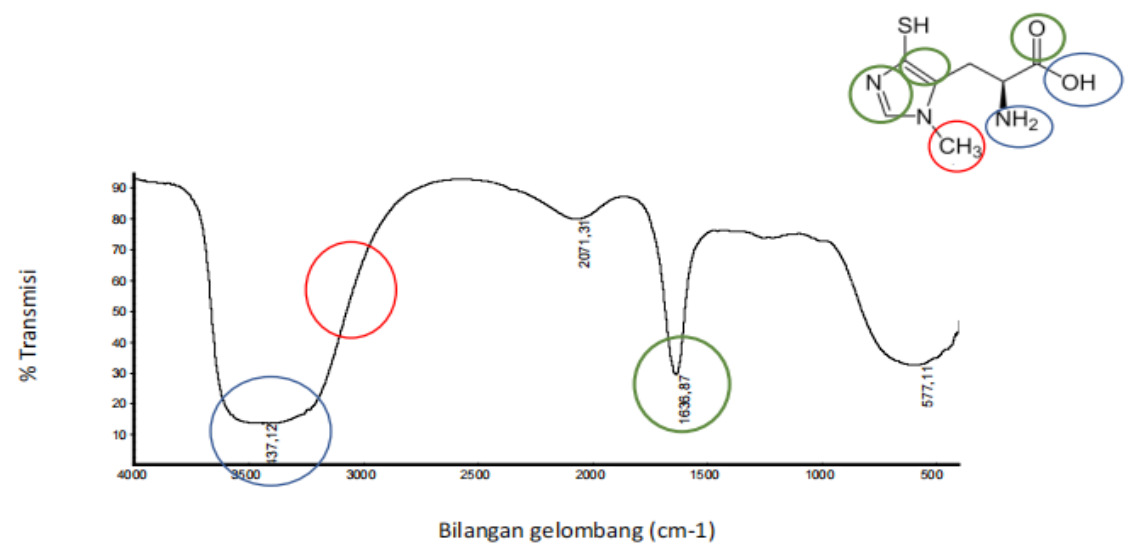

Gambar 2. Spektra hasil pengujian FTIR sampel ekstrak echinoideae Diadema setosum bagian cangkang.

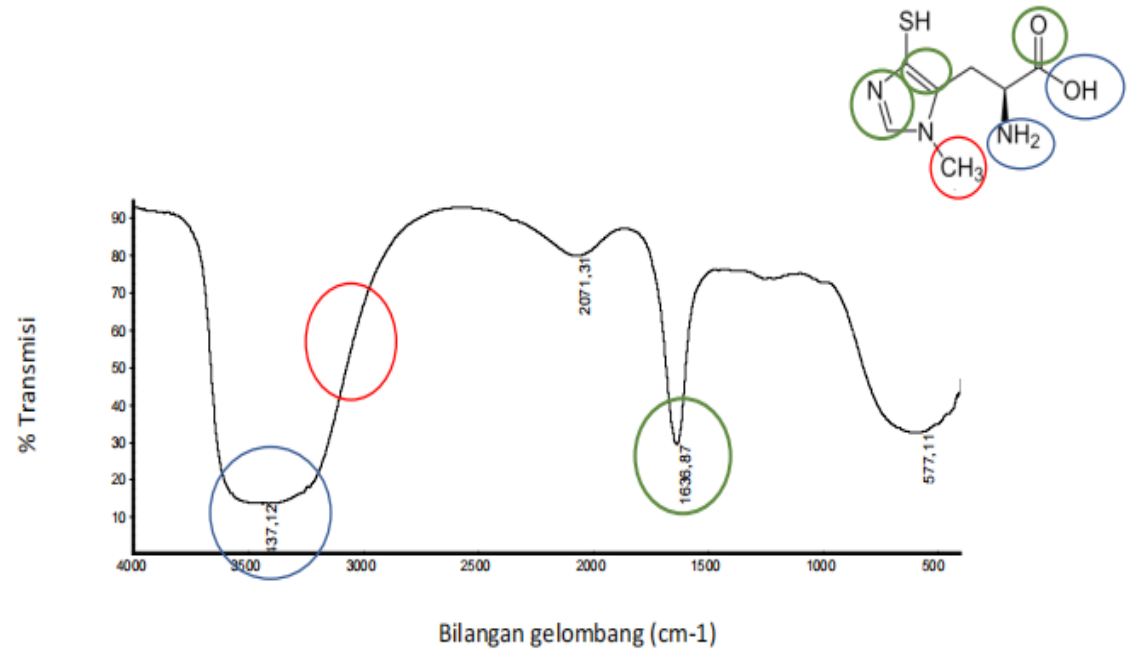

Gambar 3. Spektra hasil pengujian FTIR sampel ekstrak Echinoidea Diadema setosum bagian organ.

\section{Hasil Pengujian antibakteri dan antijamur}

Hasil Pengujian antibakteri dan antijamur ekstrak $D$. setosum disajikan pada Tabel 1 dan Tabel 2. Tabel 1 menyajikan hasil pengujian antijamur ekstrak $D$. setosum dan Tabel 2 menyajikan hasil pengujian antibakteri ekstrak D. setosum.

Pengujian ekstrak sebagai antibakteri dan antijamur dilakukan dengan variasi 4 konsentrasi yaitu $25 \%, 50 \%, 75 \%$ dan $100 \%$ dengan kontrol negatif berupa buffer fosfat $100 \%$. Kontrol positif pada pengujian ini menggunakan neomycin sulfate. Neomycin sulfate merupakan senyawa antibakteri, Menurut Rahman \& Kassab (2003), menunjukkan neomycin sulfate juga mampu bertindak sebagai senyawa antijamur. khususnya Candida albicans. Hal ini disebabkan senyawa neomycin sulfate
Tabel 1.Aktivitas Antijamur ekstrak D. setosum

\begin{tabular}{cccc}
\hline $\begin{array}{c}\text { Jenis } \\
\text { Sampel }\end{array}$ & $\begin{array}{c}\text { Konsen- } \\
\text { trasi }\end{array}$ & $\begin{array}{c}\text { Rata-rata } \\
\text { zona hambat } \\
(\mathbf{m m})\end{array}$ & $\begin{array}{c}\text { Kekuatan } \\
\text { Daya } \\
\text { Hambat }\end{array}$ \\
\hline Bagian & $25 \%$ & 0 & Tidak ada \\
Organ & $50 \%$ & 3 & Lemah \\
& $75 \%$ & 0 & Tidak ada \\
Bagian & $100 \%$ & 6.5 & Sedang \\
Cang-kang & $50 \%$ & 0 & Tidak ada \\
& $75 \%$ & 3.25 & Sedang \\
& $100 \%$ & 7 & Lemah \\
Kontrol & - & 18.25 & Kuat \\
Positif & & & Tidak ada \\
Kontrol & - & 0 & \\
Negatif & & & \\
\hline
\end{tabular}

* Kekuatan Daya Hambat mengacu pada Penelitian Susanto et al (2012) 
Tabel 2. Aktivitas Antibakteri ekstrak D. setosum

\begin{tabular}{lccl}
\hline $\begin{array}{c}\text { Jenis } \\
\text { Sampel }\end{array}$ & $\begin{array}{c}\text { Konsen- } \\
\text { trasi }\end{array}$ & $\begin{array}{c}\text { Rata-rata } \\
\text { zona hambat } \\
(\mathbf{m m})\end{array}$ & $\begin{array}{c}\text { Kekuatan } \\
\text { Daya } \\
\text { Hambat }\end{array}$ \\
\hline Bagian & $25 \%$ & 0 & Tidak ada \\
Organ & $50 \%$ & 3 & Lemah \\
& $75 \%$ & 0 & Tidak ada \\
Bagian & $100 \%$ & 6.5 & Sedang \\
Cang-kang & $50 \%$ & 0 & Tidak ada \\
& $75 \%$ & 6.375 & Sedang \\
& $100 \%$ & 7.25 & Lemah \\
Kontrol & - & 18.25 & Sedang \\
Positif & & & Kuat \\
Kontrol & - & 0 & Tidak ada \\
Negatif & & & \\
\hline
\end{tabular}

* Kekuatan Daya Hambat mengacu pada penelitian Susanto et al (2012)

mampu menghancurkan atau melisiskan biofilm yang terdapat pada sel C. albicans. Selain itu neomycin sulfate mampu mencegah adhesi dan invasi dari C. albicans terhadap media yang ditumbuhinya.

\section{Hasil Pengujian Praklinis}

Hasil pengujian praklinis terhadap penyempitan luka mencit disajikan pada Tabel 3. Pengamatan penyempitan luka dilakukan setiap hari selama 7 hari.

\section{Pembahasan}

\section{Pengujian Kromatografi Lapis Tipis}

Hasil pengujian kromatografi lapis tipis, menunjukkan bahwa terdapat spot atau noda pada plat KLT dengan nilai rf 0,15 untuk bagian cangkang Echinoidea dan 0,17 untuk bagian organ. Nilai Rf yang diperoleh ini kemudian dibandingkan dengan nilai Rf dari asam amino histidin menurut Devices (2017), yaitu 0,12 pada plat silika. Nilai Rf histidine digunakan senyawa Ovothiol A merupakan senyawa turunan L-Histidine (Anonim, 2020). Munculnya spot dengan nilai $\mathrm{Rf}$ yang mendekati dengan nilai $\mathrm{Rf}$ histidine dimungkinkan terdapat senyawa Ovothiol-A yang merupakan senyawa turunan L. Histidin.

\section{Analisis struktur Ovothiol-A dengan FTIR}

Terdapat dua spektra hasil FTIR yang ditunjukkan oleh gambar 2 dan gambar 3. Gambar 2 merupakan hasil pengujian FTIR dari sampel ekstrak $D$. setosum bagian cangkang. Spektra tersebut menunjukkan adanya puncak kuat padabilangan gelombang $1820-1660 \mathrm{~cm}^{-1}$ serta terdapat puncak melebar pada $3500 \mathrm{~cm}^{-1}$ menurut Dachriyanus (2004), hal ini menunjukkan adanya gugus karbonil amida atau $\mathrm{C}=\mathrm{O}$ amida. Puncak pada 2068,94 yang melebar menandakan adanya gugus $\mathrm{CO}^{2}$. Puncak disekitar $3000-3500 \mathrm{~cm}^{-1}$ merupakan akumulasi puncak dari gugus karboksilat $\mathrm{O}-\mathrm{H}$ atau $(\mathrm{COOH})$, gugus $\mathrm{NH}_{2}$ dari N-H stretch, dan gugus O-H. Gugus $\mathrm{COOH}$ dan $\mathrm{NH}_{2}$, merupakan gugus senyawa Ovothiol A yang teridentifikasi oleh FTIR dari sampel $D$. setosum. Hasil spektra yang menunjukkan gugus $\mathrm{O}-\mathrm{H}$ terlihat melebar yang ditunjukkan oleh lingkaran biru pada gambar 2. Menurut Dachriyanus (2004), pelebaran puncak, dapat disebabkan oleh adanya overlapping atau penumpukan gugus

Tabel 3. Hasil Pengukuran Rerata Penyempitan Luka pada Mencit Perhari (mm)

\begin{tabular}{lccccc}
\hline & \multicolumn{5}{c}{ Rerata penyempitan luka perhari (mm) } \\
\hline Mencit & $\mathrm{K}+$ & $\mathrm{K}-$ & $\mathrm{P} 1$ & $\mathrm{P} 2$ & $\mathrm{P} 3$ \\
\hline 1 & 0.25 & 0.25 & 0.43 & 0.31 & 0.62 \\
2 & 0.37 & 0.31 & 1.00 & 0.25 & 0.37 \\
3 & 0.18 & 0.25 & 0.37 & 0.62 & 0.37 \\
4 & 0.37 & 0.25 & 0.12 & 0.37 & 0.25 \\
5 & 1.25 & 0.25 & 0.25 & 0.12 & 0.37 \\
\hline Rerata & $0,4875 \pm 0,256$ & $0,26 \pm 0,256$ & $0,44 \pm 0,256$ & $0,34 \pm 0,256$ & $0,4 \pm 0,256$ \\
\hline
\end{tabular}

Keterangan:

K+: Kontrol Positif. Pemberian Bioplasenton

K-: Pemberian buffer fosfat $100 \%$

P1: Pemberian ekstrak D. setosum bagian organ konsentrasi $100 \%$

P2: Pemberian Ekstrak D. setosum bagian cangkang konsentrasi 50\%

P3: Pemberian Ekstrak D. setosum bagian cangkang dengan konsentrasi 100\% 
yang terbaca pada panjang gelombang yang berdekatan. Selain itu, puncak melebar pada panjang gelombang $300-3500 \mathrm{~cm}^{-1}$ dapat mengindikasikan masih terdapat banyak pelarut yang mungkin belum teruapkan.

Hasil identifikasi ekstrak D. setosum bagian cangkang dan organ dengan pelarut buffer fosfat pada IR, menunjukkan adanya kesamaan gugus yang teridentifikasi pada ekstrak dengan gugus yang terdapat pada Ovothiol-A, Hal ini mengindikasikan bahwa ekstrak sampel dari bagian organ dan cangkang $D$. setosum diduga senyawa Ovothiol-A. Namun, identifikasi ini masih harus dipastikan dengan metode lain karena kemungkinan adanya gugus yang terbaca pada panjang gelombang yang berdekatan dan menimbulkan keambiguan pembacaan hasil seperti kemungkinan beberapa gugus yang tidak terlihat dikarenakan berhimpitan oleh spektra yang lebih besar.

\section{Pengujian antijamur dan antibakteri}

Dari hasil pengujian yang ditunjukkan oleh Tabel 1, terdapat beberapa perlakuan yang menunjukkan rata-rata zona hambat sedang yaitu sampel bagian organ 100\% sebesar $6.5 \mathrm{~mm}$, bagian cangkang 50\% dan 100\% sebesar $6.375 \mathrm{~mm}$ dan $7 \mathrm{~mm}$. Hasil ini menunjukkan bahwa ekstrak $D$. setosum konsentrasi tinggi mampu menghambat pertumbuhan jamur C. albicans.

Perbedaan zona hambat yang ditimbulkan antara ekstrak D.setosum bagian organ dan bagian cangkang, dapat menunjukkan terdapat perbedaan konsentrasi senyawa antijamur pada kedua bagian tersebut. Pada ekstrak bagian organ konsentrasi 100\% menunjukkan zona hambat sedang. Hal ini dapat disebabkan kandungan senyawa antijamur yang diduga Ovothiol-A didalam sampel tidak terlalu banyak sehingga membutuhkan konsentrasi yang tinggi agar timbul zona hambat yang baik. Sampel bagian cangkang menunjukkan zona hambat sedang pada konsentrasi $50 \%$ dan $100 \%$. Munculnya zona hambat lemah pada konsentrasi $75 \%$ dapat dimungkinkan konsentrasi Ovothiol-A atau senyawa antijamur lainnya didalam ekstrak kecil sehingga zona hambat yang terbentuk hanya sedikit.
Ekstrak D.setosum yang dapat menghambat pertumbuhan jamur, dimungkinkan oleh kerja Ovothiol-A yang mengikat $\mathrm{H}_{2} \mathrm{O}_{2}$ pada membran plasma sehingga membrane plasma tidak dapat berkembang dengan baik karena kekurangan $\mathrm{H}_{2} \mathrm{O}_{2}$ untuk berkembang (Turner et al, 1988). Hal ini sesuai dengan penelitian yang dilakukan Pelczar \& Chan (1988), bahwa suatu zat dapat dikatakan antijamur jika menghambat pertumbuhan jamur dengan cara merusak dinding sel jamur, menghambat kerja enzim jamur, mengubah molekul protein dan asam nukleat, serta perubahan permeabilitas sel.

Menurut Evi et al (2015), selain Ovothiol-A, ekstrak D.setosum memiliki senyawa alkaloid, steroid, triterpenoid, saponin, flavonoid dan polifenol yang juga dapat berperan sebagai antijamur. Proses pemurnian yang dilakukan pada penelitian ini kemungkinan masih belum dapat memisahkan senyawa ovothiol-A dengan senyawa-senyawa aktif lain seperti yang telah disebutkan. Sehingga efek antijamur dapat ditimbulkan oleh karena senyawa tersebut.

Pengujian daya hambat sampel pada Staphylococcus aureus, menunjukkan tidak terdapat zona hambat disemua sampel atau dapat dikatakan, sampel tidak memiliki kemampuan menghambat bakteri Staphylococcus aureus. Suatu ekstrak tidak memiliki kemampuan antibakteri dapat disebabkan oleh jumlah senyawa antibakteri dalam ekstrak tersebut terlalu sedikit sehingga tidak mampu menghambat pertumbuhan bakteri. Selain itu, dapat juga disebabkan oleh adanya kontaminasi baik pada senyawa atau pada proses pengujian sehingga senyawa tidak menghambat pertumbuhan bakteri, namun justru mempercepat pertumbuhan bakteri. Hal ini sesuai dengan penelitian yang dilakukan (Shamsudin et al, 2010), bahwa ketidak mampuan suatu ekstrak menghambat pertumbuhan bakteri, dapat dimungkinkan karena komponen non-aktif seperti pelarut atau senyawa-senyawa lain yang bukan senyawa aktif dari ekstrak mengganggu komponen aktif dan aktifitas penghambatan. 
Hasil penelitian yang dilakukan Marimutuhu et al. (2015), Ekstrak bagian organ terutama bagian ovarium dari $D$. setosum memiliki kemampuan menghambat bakteri gram positif dan bakteri gram negatif termasuk $S$. aureus. dan penelitian yang dilakukan (Shankarlal et al, 2011) Ekstrak bagian cangkang dari Echinoidea dari spesies Salmacis virgulata memiliki kemampuan menghambat pertumbuhan jamur C.albicans pada konsentrasi tertinggi yaitu $1000 \mu$ g dengan zona hambat sebesar $9 \mathrm{~mm}$. Berbeda dengan hasil penelitian yang telah dilakukan bahwa ekstrak D. setosum tidak memiliki kemampuan menghambat bakteri $S$. aureus. Hal ini dapat disebabkan oleh, perbedaan spesies Echinoidea yang digunakan dan kondisi lingkungan dari Echinoidea tersebut hidup. Perbedaan spesies dan lingkungan mempengaruhi metabolit sekunder yang dihasilkan. Selain itu, kemampuan menghambat bakteri juga berbeda dari penelitian yang pernah dilakukan karena perbedaan konsentrasi senyawa antibakteri pada ekstrak yang digunakan dalam peneltian. Dikarenakan pada penelitian ini tidak dilakukan uji kuantitatif terhadap jumlah senyawa antibakteri pada ekstrak sehingga tidak dapat diketahui jumlah pasti senyawa antibakteri yang terdapat pada ekstrak D. setosum.

\section{Pengujian Praklinis}

Hasil pengukuran luka mencit, dihitung dengan menggunakan rerata penyempitan luka perhari ditunjukkan pada Tabel 3. Hasil yang didapatkan menunjukkan bahwa rerata penyempitan luka perhari mencit yang diberi perlakuan kontrol positif, ekstrak $D$. setosum bagian organ dengan konsentrasi $100 \%$, ekstrak D. setosum bagian cangkang dengan konsentrasi $50 \%$, dan ekstrak $D$. setosum bagian cangkang dengan konsentrasi $100 \%$ lebih tinggi dibandingkan dengan mencit yang diberikan kontrol negatif berupa buffer fosfat. Jika dibandigkan dengan kontrol positif, ketiga perlakuan, memiliki rerata penyempitan luka yang lebih rendah dari 0,4875 $\pm 0,256 \mathrm{~mm}$. Hasil dari ketiga perlakuan yang diberikan menunjukkan bahwa penyempitan luka mencit yang diberi perlakuan ekstrak $D$. setosum bagian cangkang dengan konsentrasi 50\% memiliki rerata penyempitan luka paling kecil yaitu $0.33 \mathrm{~mm}$ per hari. Rerata penyempitan luka yang paling tinggi adalah mencit yang diberi perlakuan ekstrak $D$. setosum bagian organ dengan konsentrasi 100\% yaitu 0,4375 mm perhari. Hasil pengujian praklinis yang dilakukan ini, menunjukkan bahwa pada ekstrak $D$. setosum baik bagian organ maupun bagian cangkang terdapat senyawa yang mampu berperan sebagai antiinflamasi pada luka. Senyawa ini, dimungkinkan adalah Ovothiol-A. Hal ini hampir sama dengan penelitian yang dilakukan oleh (Karmilah \& Badia, 2019), bahwa ekstrak gonad D. setosum memiliki kemampuan sebagai penyembuh luka bakar dikarenakan terdapat senyawa yang dapat berperan sebagai antibakteri dan juga antiinflamasi. Senyawa senyawa ini dapat mempercepat penyembuhan luka.

Hasil pengujian praklinis menunjukkan terjadinya penyempitan luka pada semua perlakuan baik ekstrak $D$. setosum bagian organ maupun cangkang. Hal ini dapat disebabkan oleh, kemampuan Ovothiol-A mampu berperan sebagai antiinflamasi yang mencegah stress oksidatif berlebihan. Menurut Arief \& Widodo (2016), stres oksidatif yang berlebihan dapat menghambat penyembuhan luka sehingga hal ini harus dicegah agar penyembuhan luka lebih cepat.

\section{Kesimpulan}

Ekstrak eter Diadema setosum bagian cangkang dan organ mengandung senyawa yang diduga Ovothiol-A berdasarkan hasil analisis KLT dan FTIR. Senyawa yang diduga sebagai Ovothiol-A pada ekstrak eter $D$. setosum ini memiliki kemampuan sebagai antiinflamasi, dan antijamur Candida albicans. Ekstrak organ D. setosum memiliki kemampuan antiinflamasi yang lebih baik bagian cangkang yang ditunjukkan dari tingginya rerata penyempitan luka mencit yang diberi ekstrak bagian organ yaitu 0,44 $\pm 0,256 \mathrm{~mm} /$ hari.

\section{Daftar Pustaka}

Anonim.(2020). Ovothiol A. National Center for Biotechnology Information Retrieved from PubChem: https://pubchem.ncbi. 
nlm.nih.gov/compound/Ovothiol-A. diakses 13 November 2020

Aprilia, Ayu, H., Pringgenies, D., \& Yudiati, E. (2012). Uji Toksisitas Ekstrak Kloroform Cangkang dan Duri Landak Laut (Diadema setosum) terhadap mortalitas Nauplius asrtemia sp. Journal of Marine Reasearch, 1(1), 75-83.

Arief, H \& Widodo, A, M. (2016). Peranan Stress Oksidatif Pada Proses Penyembuhan Luka. Jurnal Ilmiah Kedokteran Wijaya Kusuma, 5(2), 22-29.

Aziz, A. (1993). Beberapa Catatan tentang Perikanan Bulu Babi. Oseana, 18 (2), 65-75.

Dachriyanus. (2004). Analisis Struktur Senyawa Organik Secara Spektroskopi. Padang: Lembaga Pengembangan Teknologi Informasi dan Komunikasi (LPTIK) Universitas Andalas.

Darsono, P \& Aziz, A. (1979). Reproduksi bulu babi, Diadema setosum di daerah gugus Pulau Pari, Pulau-pulau Seribu, Jakarta. Prosiding Kongres Nasional Biologi IV. Bandung, 10

Devices, R. (2017). TLC Amino Acids. Retrieved from REACH Devices Made in USA: http://www.reachdevices. com/TLC_aminoacids.html. diakses 13 November 2020

Evi, M., Alimuddin, A. H., \& Destiarti, L. (2015). Pemanfaatan Ekstrak Landak Laut (Diadema setosum) dari Pulau Lemukutan Sebagai Antijamur Candida albicans. Jurnal Kimia Khatulistiwa, 4(4).

Karmilah, \& Badia, E. (2019). Pengaruh Bentuk Sediaan Ekstrak Gonad Landak Laut (Diadema setosum) Sebagai Penyembuh Luka Bakar pada Kelinci (Oryctolagus cuniculus). Window Of Health, 65.

Marimutuhu, K., Gunaselvam, P., Rahman, M. A., \& Savier, R. (2015). Antibacterial activity of Ovary Extract From Sea Urchin Diadema setosum. European Review for Medical and Pharmacological Sciences, 1895-1899.

Pelczar, M. J \& Chan, E. C. (1988). DasarDasar Mikrobiologi. Jakarta: Universitas Indonesia Press.

Rahman, G. A \& Kassab, N. H. (2003). Neomycin sulfate: A new antifungal and antiadherent agent against Candida albicans cells on heat-cured acrylic resin denture base material. An in vitro study. Al-Rafidain Dental Journal, 139-142.

Rompis, B. R., Langoy, M. L .D., Katili, D. Y \& Papu, A. (2013). Diversitas Echinodermata di Pantai Meras Kecamatan Bunaken Sulawesi Utara. Bioslogos, 3(1), 26-31.

Shamsudin, Hakim, L., Kumari, \& Noraznawati. (2010). Anti-Bacterial Activity of Three Species Of Sea Urchin Extracts from Pulau Bidong, Terengganu. Journal of Sustaibility Science and Management, 5(1), 116-124.

Shankarlal, S., Prabu, K., \& Natarajan, E. (2011). Antimicrobial and Antioxidant Actyvity of Purple Sea Urchin Shell (Salmacis virgulata L. Agassiz and Desor 1846). American-Eurasian Journal of Scientific Research, 178-181.

Susanto., Sudrajat, D., \& Ruga, R. (2012). Studi kandungan bahan aktif tumbuhan meranti merah (Shorea leprosula Miq) sebagai sumber senyawa antibakteri. Mulawarman Scientific, 11(2), 181-190.

Turner, E., Hager, L., \& Shapiro, B. (1988). Ovothiol replaces glutathione peroxidase as a hydrogen peroxide scavenger in sea urchin eggs. Science 242, 939-941.

Widiyantoro, A., Lia D., Indri K., Supardi, Dedy G. H., \& Niwick. (2012). Aktivitas Antiinflamsi Senyawa Bioaktif dari Kulit Batang Pauh Kijang (Irvingia malayana Oliv. Ex. A. Benn) Terhadap Tikus Putih (Rattus norvegicus) yang Diinduksi Karagenan. Kaunia 8(2):118126. 